\title{
Nīlakaṇtha's Value of R-Sine for the Arc of Twenty-four Degrees
}

\author{
Takao Hayashi* \\ (Received 20 June 2015; revised 10 August 2015)
}

\begin{abstract}
In an algorithm in astronomy, Nīlakantha uses the integral constant 8452 as a divisor in place of $R^{2} / R \sin 24^{\circ}$ without specifying the values of $R$ and $R \sin 24^{\circ}$ he employed. In this paper I propose to determine their probable values.
\end{abstract}

Key words: Interpolation, Mādhava, Power series, Sine table

\section{Definitions}

For an arc $x$ measured in kala (minute) in a quarter circle with radius $R$, let $J(x)$ be half of the chord $(j y \bar{a})$ subtending the arc $2 x$, and let $J^{\prime}(x)$ $=J(90 \cdot 60-x)$. Let a unit arc be $\alpha=(90 \cdot 60) / n$ for an optionally chosen integer $n$, and $J_{i}=J\left(\alpha_{i}\right)$, where $\alpha_{i}=i \cdot \alpha(i=1,2, \cdots, n) ; J_{i}$ are the tabulated values of the $n R$-sines for a circle with radius $R$. Finally, let the sine differences be $K_{i}=J_{i}-J_{i-1}\left(J_{0}\right.$ $=0)$.

\section{Problem}

Nīlakantha prescribes an algorithm for calculating the drkksepa (zenith distance of the nonagesimal) in two verses of his two works, Tantrasamgraha and Candracchāyāganita [TS $3.104 \mathrm{~cd}-106 \mathrm{ab}=$ CC 9-10]; in the algorithm he uses the integral number 8452 as a divisor (cf. [Ramasubramanian et al. (2011), pp.242- 45). He cites the same verses in his commentary on the fourth chapter of the Aryabhatizya [NAB4, p.118, line 23 to p.119, line 2] and explains how to derive the algorithm, mentioning that the integer 8452 has been obtained by reducing a multiplier $J$ (1440), where $1440^{\prime}$ or $24^{\circ}$ is the sun's maximum declination, and a divisor $R^{2}$ that occur in the process of derivation to a single number by means of a 'shortcut' (laghu-tantra). In his commentary on the second chapter of the Aryabhatīya [NAB2, p.53, lines 19-22] Nīlakaṇtha cites the 'shortcut' given in two verses from Govinda-svāmin's commentary on the Mahābhāskarīya [GMB 1.23,

p.33], which teaches that the calculation, $\frac{a \times b}{c}$,

can be replaced by another, $\frac{a \times b^{\prime}}{c^{\prime}}$, where $c^{\prime}=\frac{c \times b^{\prime}}{b}$ when $b^{\prime}$ is an optionally determined number (mati) or $b^{\prime}=\frac{b \times c^{\prime}}{c}$ when $c^{\prime}$ is optionally determined. This calculation, either for $c^{\prime}$ or for $b^{\prime}$, is carried out in the form of trairāśika (socalled rule of three). In the former case, for example, the verbal formulation (vācoyukti) of the trairāsika is: 'If $c$ is obtained from $b$, then what is obtained from $b^{\prime}$ ?', which may be expressed in modern notation as $b: c=b^{\prime}: x$, and the result is $c^{\prime}$. In the present case, after formulating the trairāsika with $b^{\prime}=1$, Nīlakantha says that the result is 8452 . Expressed in modern notation,

$J(1440): R^{2}=1: x \rightarrow x=\frac{R^{2}}{J(1440)}=8452$ 
He, however, does not refer to the values of $R$ and $J(1440)$ he used here.

Bhāskara II assigns 1397 for $R \sin 24^{\circ}$ in his Golādhyāya [GA, spaștāadhikāra 12c]. This value, 1397, can be obtained from his $J_{i}$ [GG 2.34], which except $J_{16}=2977$ are exactly the same as Āryabhata's, by means of linear interpolation (see $\S 4 \mathrm{a}$ below). However, from this value with Âryabhata's $R=3438$, we obtain $R^{2} / J(1440)$ $=8460 ; 52,23, \ldots$, which is greater than 8452 by nearly 9 kalās. We, therefore, have to seek for other pair of values for Nīlakaṇtha's $R$ and $J(1440)$.

Nīlakantha himself prescribes two recursion methods for constructing tables of $J_{i}$ ([TS 2.3cd-10ab]; see Appendix A) and one method for interpolation [TS 2.17-20]. It may, therefore, be natural to assume that he himself obtained $J(1440)$ by using his own $J_{i}$ tables with the interpolation. But the Kerala tables of $J_{i}$, including Nīlakantha's, are variations of Äryabhata's table in the sense that they use $R=$ 3438 or revised ones and $n=24$. Moreover, as the arc of 1440 kalās has a special significance in Indian astronomy, there is also the possibility that the value of $J(1440)$ used by Nīlakantha had already been obtained by his predecessors. Hence, it is worthwhile to see if 8452 can be obtained by means of an appropriate interpolation from other tables with $R=3438$ or with similar values. I shall examine which combination of $J_{i}$ tables and methods of interpolation can produce the number 8452 .

The $J_{i}$ tables used here for calculation are:

a. Āryabhata's table reconstructed from his table of $K_{i}$ [AB 1.12 (1.10 in earlier editions); see Hayashi (1997), p.402, Table 1]. This table has been adopted in the Süryasiddhānta, one of the most influential astronomical works, and by Bhāskara II, one of the most influential astronomers. b. Āryabhata's reconstructed table with minor corrections $\left[J_{i}^{*}\right.$ in Hayashi (1997), p.402, Table $1]$.

c. Āryabhața's table corrected by Govindasvāmin [GMB 4.22, p.200; cf. Gupta (1971), pp.53-54 and Table 1; cf. also Mallayya (2014), p.148, Table 4].

d. Mādhava's table cited by Nīlakaṇtha and by Śankara [see Appendix B].

e. Nīlakantha's table reconstructed from his first recursion method [TS 2.3cd-6ab; see Appendix A1].

f. Nīlakantha's table reconstructed from his second recursion method [TS 2.6cd-10ab; see Appendix A2].

The methods of interpolation examined here are:

1. Linear interpolation.

2. Nīlakantha's interpolation which utilizes the sum and difference formulas for $J(x)$ and $J^{\prime}$ (x) [TS 2.17-20].

3. Mādhava's second order interpolation (cited in [TS 2.10cd-13] and in [NAB2, p.55, lines 1-7]).

4. Brahmagupta's second order interpolation [BSS $25.17=$ KhKh II, 1.4; adopted in GG 2.16].

5. Govindasvāmin's second order interpolation [GMB 4.22, pp.201-02; cf. Gupta (1969), pp.91-92].

Besides these interpolations, I shall examine the two formulas that directly produce $J(x)$ for any $\operatorname{arc} x$, namely,

6. Bhāskara I's rational approximation formula, and

7. Mādhava's power series expansion.

The former [MB 7.17-18], or one of its equivalents, has been adopted by other 
astronomers beginning with Brahmagupta [BSS 14.23-24]. The latter has been cited by Śankara Vāriyar [YD 2.440-41 ₹ 2.451-52; KK on L 199, p.390]. As A. K. Bag points out [Bag (1976), pp.54-56; cf. Ramasubramanian et al. (2011), p.63], Mādhava's table of $J_{i}$ with the two sexagesimal places, vikalā and tatpara $\bar{a}$, can be obtained by means of this power series (see Appendix B).

Finally, I shall also examine the value of $J(1440)$ given by Vateśvara, a follower of Āryabhata, who however uses a $J_{i}$ table with $n=$ 96 instead of $n=24$.

For the dates of the astronomers and of their works consult general works on the history of mathematics and astronomy in India.

\section{REQUIREMENTS}

The nearest integer to $R^{2} / J(1440)$ is 8452 when and only when the quotient of the division of $R^{2}$ by $J(1440)$ lies between $8451 ; 30$ and $8452 ; 30$, that is,

$$
8451 ; 30 \leq \frac{R^{2}}{J(1440)}<8452 ; 30,
$$

which can be rewritten as

$$
\frac{R^{2}}{8452 ; 30}<J(1440) \leq \frac{R^{2}}{8451 ; 30} .
$$

3a and 3b. Since $R=3438$, we have $R^{2}=$ 11819844 and

$$
\begin{aligned}
& R^{2} / 8452 ; 30=1398 ; 23,3,46, \ldots \\
& R^{2} / 8451 ; 30=1398 ; 32,59,26, \ldots
\end{aligned}
$$

Hence follows the requirement: $59,26, \ldots$

$$
1398 ; 23,3,46, \ldots<J(1440) \leq 1398 ; 32,
$$

3c. Since $R=3437 ; 44,19$, we have $R^{2}=$ $11818046 ; 45,29,58,1$ and

$$
R^{2} / 8452 ; 30=1398 ; 10,18,19, \ldots
$$

$R^{2} / 8451 ; 30=1398 ; 20,13,52, \ldots$

Hence follows the requirement:

$1398 ; 10,18,19, \ldots<J(1440) \leq 1398 ;$

$20,13,52, \ldots$

3d. Since $R=3437 ; 44,48$, we have $R^{2}=$ $11818102 ; 8,39,2,24$ and

$$
\begin{aligned}
& R^{2} / 8452 ; 30=1398 ; 10,41,54, \ldots \\
& R^{2} / 8451 ; 30=1398 ; 20,37,28, \ldots
\end{aligned}
$$

Hence follows the requirement:

$1398 ; 10,41,54, \ldots<J(1440) \leq 1398 ;$

$20,37,28, \ldots$

3e. Since $R=3437$; 28, we have $R^{2}=11816177$; 5; 4 and

$$
\begin{aligned}
& R^{2} / 8452 ; 30=1397 ; 57,2,0, \ldots \\
& R^{2} / 8451 ; 30=1398 ; 6,57,28, \ldots
\end{aligned}
$$

Hence follows the requirement: $57,28, \ldots$

$1397 ; 57,2,0, \ldots<J(1440) \leq 1398 ; 6$,

3f. Since $R=3437 ; 44,47$, we have $R^{2}=11818100$; $14,3,32,49$ and

$$
\begin{aligned}
& R^{2} / 8452 ; 30=1398 ; 10,41,5, \ldots \\
& R^{2} / 8451 ; 30=1398 ; 20,36,39, \ldots
\end{aligned}
$$

Hence follows the requirement: $36,39, \ldots$

$1398 ; 10,41,5, \ldots<J(1440) \leq 1398 ; 20$,

In each of $3 a \sim 3 f$, the possible range for $J(1440)$ has the width of about 10 vikalās.

\section{LINEAR INTERPOLATION}

When $0<\varepsilon \leq \alpha / 2$,

$J\left(\alpha_{i} \pm \varepsilon\right)=J_{i} \pm \frac{\left(J_{i+1}-J_{i}\right) \varepsilon}{\alpha}=J_{i}+\frac{\varepsilon}{\alpha} \cdot K_{i+1} \cdot$

For $n=24$ we have $\alpha=225,1440=\alpha_{6}+90$, and

$$
J(1440)=J_{6}+\frac{2}{5} \cdot\left(J_{7}-J_{6}\right)=J_{6}+\frac{2}{5} \cdot K_{7} .
$$


4a. Since $J_{6}=1315$ and $J_{7}=1520$, we have $J(1440)$ $\approx 1397$, which does not fulfill the requirement (see 3a above).

4b. Since $J_{6}=1316$ and $J_{7}=1521$, we have $J(1440)$ $\approx 1398$, which does not fulfill the requirement (3a).

4c. Since $J_{6}=1315 ; 33,56$ and $J_{7}=1520 ; 28,22$, we have $J(1440) \approx 1397 ; 31$, 42, which does not meet the requirement $(3 \mathrm{c})$.

4d. Since $J_{6}=1315 ; 34,7$ and $J_{7}=1520 ; 28,35$, we have $J(1440) \approx 1397$; 31, 54, which does not fulfill the requirement $(3 \mathrm{~d})$.

4e. Since $J_{6}=1315 ; 32$ and $J_{7}=1520 ; 26$, we have $J(1440) \approx 1397 ; 30$, which does not fulfill the requirement $(3 \mathrm{e})$.

4f. Since $J_{6}=1315 ; 34,7$ and $J_{7}=1520 ; 28,35$, we have $J(1440) \approx 1397 ; 31$, 54, which does not fulfill the requirement $(3 \mathrm{f})$.

\section{NīLAKAṆTHA's INTERPOLATION}

When $0<\varepsilon \leq \alpha / 2$,

$$
\begin{aligned}
& J\left(\alpha_{i}+\varepsilon\right)=\frac{J_{i} \cdot J^{\prime}(\varepsilon) \pm J_{i}^{\prime} \cdot J(\varepsilon)}{R}, \\
& J^{\prime}\left(\alpha_{i}+\varepsilon\right)=\frac{J_{i}^{\prime} \cdot J^{\prime}(\varepsilon) \mp J_{i} \cdot J(\varepsilon)}{R}
\end{aligned}
$$

where

$$
J(\varepsilon)=\varepsilon-\frac{\varepsilon^{3}}{6 R^{2}},
$$

as $\varepsilon$ is small enough, and

$$
J^{\prime}(\varepsilon)=\sqrt{R^{2}-J(\varepsilon)^{2}} .
$$

The last relationship is mentioned in TS 2.14ab.

For our case,

$$
J(1440)=J\left(\alpha_{6}+90\right)=\frac{J_{6} \cdot J^{\prime}(90)+J_{6}^{\prime} \cdot J(90)}{R},
$$

where

$$
J(90)=\frac{540 R^{2}-729000}{6 R^{2}}, J^{\prime}(90)=\sqrt{R^{2}-J(90)^{2}} .
$$

5a. Since $R=3438, J_{6}=1315$, and $J_{6}^{\prime}=J_{18}=3177$, we have $J(90) \approx 89 ; 59,23, J^{\prime}(90) \approx 3436 ; 49,19$, and $J(1440) \approx 1397 ; 42,26$, which does not meet the requirement (3a).

5b. Since $R=3438, J_{6}=1316$, and $J_{6}^{\prime}=J_{18}=3176$, we have $J(90) \approx 89 ; 59,23, J^{\prime}(90) \approx 3436 ; 49,19$, and $J(1440) \approx 1398 ; 40,51$, which does not meet the requirement $(3 \mathrm{~b})$.

5c. Since $R=3437 ; 44,19, J_{6}=1315 ; 33,56$, and $J_{6}^{\prime}=J_{18}=3176 ; 3,23$, we have $J(90) \approx 89 ; 59,22$, $59, J^{\prime}(90) \approx 3436 ; 33,42,48$, and $J(1440) \approx 1398$; 15,18 , which meets the requirement $(3 \mathrm{c})$ : $R^{2} / J(1440)=8451 ; 59,48, . . \approx 8452$.

5d. Since $R=3437 ; 44,48, J_{6}=1315 ; 34,7$, and $J_{6}^{\prime}=J_{18}=3176 ; 3,50$, we have $J(90) \approx 89 ; 59,22$, $59, J^{\prime}(90) \approx 3436 ; 34,7,7$, and $J(1440) \approx 1398$; 15,39 , which meets the requirement $(3 \mathrm{~d})$ : $R^{2} / J(1440)=8452 ; 0 ; 4, \ldots \approx 8452$.

5e. Since $R=3437 ; 28, J_{6}=1315 ; 32$, and $J_{6}^{\prime}=J_{18}$ $=3175 ; 53$, we have $J(90) \approx 89 ; 59,23, J^{\prime}(90) \approx$ $3436 ; 17,18$, and $J(1440)=1398 ; 6,48,32, \ldots \approx$ 1398; 7, which does not meet the requirement (3e). The result of the calculation up to the second sexagesimal place, $1398 ; 6,48$, meets the requirement but the second place is not valid in this case (see Appendix A1).

5f. Since $R=3437 ; 44,47, J_{6}=1315 ; 34,7$, and $J_{6}^{\prime}=J_{18}=3176 ; 3,49$, we have $J(90)=89 ; 59,22$, $59, J^{\prime}(90)=3436 ; 34,6,5$, and $J(1440) \approx 1398$; 15,27 , which meets the requirement (3f): $R^{2} /$ $J(1440)=8452 ; 1,11, \ldots \approx 8452$.

\section{MÁdHAVA's SECOND ORder INTERPOLATION}

When $0<\varepsilon \leq \alpha / 2$, let $D=13751 /(2 \varepsilon)$. Then

$$
J\left(\alpha_{i} \pm \varepsilon\right)=J_{i} \pm \frac{2}{D} \cdot\left(J_{i}^{\prime} \mp \frac{J_{i}}{D}\right)
$$

$$
J^{\prime}\left(\alpha_{i} \pm \varepsilon\right)=J_{i}^{\prime} \mp \frac{2}{D} \cdot\left(J_{i} \pm \frac{J_{i}^{\prime}}{D}\right) .
$$


For our case, $\varepsilon=90, D=13751 / 180$ and

$$
J(1440)=J_{6}+\frac{2}{D} \cdot\left(J_{6}^{\prime}-\frac{J_{6}}{D}\right) .
$$

The number 13751 in $D$ is the nearest integer to $4 R$ with Mādhava's $R$ : 13751.

$$
4 R=4 \cdot 3437 ; 44,48=13750 ; 59,12 \approx
$$

It seems that the dividend and the divisor of the right-hand side of $D=2 R / \varepsilon$ have been doubled so that the dividend, which will turn out to be a divisor in the above calculation, might become an integer, which would make the calculation easier.

For Govindasvāmin's $R$ reconstructed from [GMB 4.22] also (see [Mallayya (2014), p.148, Table 4]), we have $\approx 13751$.

$$
4 R=4 \cdot 3437 ; 44,19=13750 ; 57,16
$$

Also for Nīlakantha's $R$ reconstructed from [TS 2.6cd-10ab] (see Appendix A2), we have

$$
4 R=4 \cdot 3437 ; 44,47=13750 ; 59,8
$$
$\approx 13751$.

But, for Nīlakantha's another $R$ reconstructed from [TS 2.3cd-6ab] (see Appendix A1), we have

$$
4 R=4 \cdot 3437 ; 28=13749 ; 52 \approx 13750 \text {. }
$$

On the other hand, for Āryabhata's $R=$ 3438 , we have $D=6876 / \varepsilon$.

6a. Since $R=3438, J_{6}=1315$, and $J_{6}^{\prime}=J_{18}=3177$, we have $D=6876=90$ and $J(1440) \approx 1397 ; 43,1$, which does not fulfill the requirement (3a).

6b. Since $R=3438, J_{6}=1316$, and $J_{6}^{\prime}=J_{18}=3176$, we have $D=6876 / 90$ and $J(1440) \approx 1398 ; 41,26$, which does not fulfill the requirement (3b).

6c. Since $R=3437 ; 44,19, J_{6}=1315 ; 33,56$, and $J_{6}^{\prime}=J_{18}=3176 ; 3 ; 23$, we have $D=13751 / 180$, and $J(1440) \approx 1398 ; 15,49$, which meets the requirement $(3 \mathrm{c})$. 6d. Since $R=3437 ; 44,48, J_{6}=1315 ; 34,7$, and $J_{6}^{\prime}=J_{18}=3176 ; 3$, 50, we have $D=13751 / 180$ and $J(1440) \approx 1398 ; 16$, 1, which fulfills the requirement $(3 \mathrm{~d})$.

6e. Since $R=3437 ; 28, J_{6}=1315 ; 32$, and $J_{6}^{\prime}=J_{18}$ $=3175 ; 53$, we have $D=13750 / 180$ and $J(1440)$ $\approx 1398 ; 14$, which does not fulfill the requirement $(3 \mathrm{e})$.

6f. Since $R=3437 ; 44,47, J_{6}=1315 ; 34,7$, and $J_{6}^{\prime}=J_{18}=3176 ; 3,49$, we have $D=13751 / 180$ and $J(1440) \approx 1398 ; 16,0$, which fulfills the requirement $(3 \mathrm{f})$.

\section{BRAHMAguPTA'S SECOND ORDER INTERPOLATION}

When $0<\varepsilon<\alpha$,

$$
J\left(\alpha_{i}+\varepsilon\right)=J_{i}+\frac{\varepsilon}{\alpha} \cdot \frac{K_{i}+K_{i+1}}{2}-\left(\frac{\varepsilon}{\alpha}\right)^{2} \cdot \frac{K_{i}-K_{i+1} .}{2}
$$

For our case,

$$
J(1440)=J_{6}+\frac{K_{6}+K_{7}}{5}-\frac{2\left(K_{6}-K_{7}\right)}{25} .
$$

7a. Since $J_{6}=1315, K_{6}=210$, and $K_{7}=205$, we have $J(1440) \approx 1397 ; 36$, which does not fulfill the requirement $(3 a)$.

7b. Since $J_{6}=1316, K_{6}=211$, and $K_{7}=205$, we have $J(1440) \approx 1398 ; 43,12$, which does not fulfill the requirement $(3 b)$.

7c. Since $J_{6}=1315 ; 33 ; 56, K_{6}=210 ; 32 ; 26$, and $K_{7}=204 ; 54,26$, we have $J(1440) \approx 1398 ; 12,16$, which meets the requirement $(3 \mathrm{c})$.

7d. Since $J_{6}=1315 ; 34,7, K_{6}=210 ; 32,29$, and $K_{7}=204 ; 54,28$, we have $J(1440) \approx 1398 ; 12,28$, which fulfills the requirement (3d).

7e. Since $J_{6}=1315 ; 32, K_{6}=210 ; 32$, and $K_{7}=$ $204 ; 54$, we have $J(1440) \approx 1398 ; 10$, which does not fulfill the requirement $(3 \mathrm{e})$. 
7f. Since $J_{6}=1315 ; 34,7, K_{6}=210 ; 32,29$, and $K_{7}=204 ; 54,28$, we have $J(1440) \approx 1398 ; 12,28$, which fulfills the requirement (3f).

\section{Govindasvāmin's Second Order INTERPOLATION}

When $0<\varepsilon<\alpha$,

$$
J\left(\alpha_{i}+\varepsilon\right)=J_{i}+\frac{\varepsilon}{\alpha} \cdot K_{i+1}+E,
$$

where

$$
\begin{aligned}
& E=\frac{1}{4} \cdot \frac{3 \varepsilon(\alpha-\varepsilon)}{\alpha^{2}} \cdot\left(K_{i}-K_{i+1}\right)(\text { for } i=1 \text { to } 7), \\
& E=\frac{1}{6} \cdot \frac{3 \varepsilon(\alpha-\varepsilon)}{\alpha^{2}} \cdot\left(K_{i}-K_{i+1}\right)(\text { for } i=8 \text { to } 15), \\
& E=\frac{1}{47-2 i} \cdot \frac{\alpha-\varepsilon}{\alpha} \cdot \frac{\varepsilon}{\alpha} \cdot K_{i+1}(\text { for } i=16 \text { to } 23) .
\end{aligned}
$$

For our case $(i=6)$,

$$
J(1440)=J_{6}+\frac{2}{5} \cdot K_{7}+\frac{9}{50} \cdot\left(K_{6}-K_{7}\right)
$$

The results of the calculations, none of which meets the requirements, are shown in Table 2.

\section{Bhāskara I's Rational Approximation}

When the $\operatorname{arc} \theta$ is measured in degree,

$$
R \sin \theta=\frac{R \theta(180-\theta)}{[40500-\theta(180-\theta)] / 4} .
$$

For $x$ measured in kalā, we have

$$
J(x)=\frac{R \cdot \frac{x}{60}\left(180-\frac{x}{60}\right)}{\left[40500-\frac{x}{60}\left(180-\frac{x}{60}\right)\right] / 4} .
$$

For our case,

$$
J(1400)=\frac{416}{1021} R .
$$

The results of the calculations, none of which meets the requirements, are shown in Table 2 .

\section{MĀDHAVA's POWER SERIES EXPANSION}

For $n \geq 2$,

$$
\begin{aligned}
& J(x)=x-x \cdot \frac{x^{2}}{\left(2^{2}+2\right) R^{2}}+x \cdot \frac{x^{2}}{\left(2^{2}+2\right) R^{2}} \cdot \frac{x^{2}}{\left(4^{2}+4\right) R^{2}}-\ldots \\
& +(-1)^{n-1} x \cdot \frac{x^{2 n-2}}{\left(2^{2}+2\right)\left(4^{2}+4\right) \ldots\left\{(2 n-2)^{2}+(2 n-2)\right\} R^{2 n-2}}
\end{aligned}
$$

For this formula see Appendix B. Table 1 shows $J(1440)$ obtained by means of this formula for $n=2,3,4,5$, and 100 . The underlined values meet the requirements. Interestingly, with

\begin{tabular}{|c|c|c|c|c|c|}
\hline$n$ & $\begin{array}{c}\text { a,b. Ārya } \\
R=3438\end{array}$ & $\begin{array}{l}\text { c. Govinda } \\
3437 ; 44,19\end{array}$ & $\begin{array}{c}\text { d. Mādhava } \\
3437 ; 44,48\end{array}$ & $\begin{array}{c}\text { e. Nīla-A1 } \\
3437 ; 28\end{array}$ & $\begin{array}{l}\text { f. Nīla-A2 } \\
3437 ; 44,47\end{array}$ \\
\hline 2 & $1397 ; 53,45,12,27$ & $1397 ; 53,22,09,24$ & $1397 ; 53,22,51,57$ & $1397 ; 52,58,10,12$ & $1397 ; 53,22,50,39$ \\
\hline 3 & $1398 ; 15,54,46,26$ & $\underline{1398 ; 15,22,07,48}$ & $\underline{1398 ; 15,32,49,29}$ & $1398 ; 15,08,33,38$ & $\underline{1398 ; 15,32,48,11}$ \\
\hline 4 & $1398 ; 15,49,13,09$ & $\underline{1398 ; 15,26,34,30}$ & $\underline{1398 ; 15,27,16,12}$ & $1398 ; 15,03,00,08$ & $1398 ; 15,27,14,54$ \\
\hline 5 & $1398 ; 15,49,14,00$ & $\underline{1398 ; 15,26,35,22}$ & $\underline{1398 ; 15,27,17,03}$ & $1398 ; 15,03,01,00$ & $1398 ; 15,27,15,46$ \\
\hline 100 & $1398 ; 15,49,14,00$ & $1398 ; 15,26,35,22$ & $1398 ; 15,27,17,03$ & $1398 ; 15,03,01,00$ & $1398 ; 15,27,15,46$ \\
\hline
\end{tabular}
Govindasvāmin's $R=3437 ; 44,19$, Mādhava's $R$ $=3437 ; 44,48$ and Nīlakantha's $R=3437 ; 44,47$, calculation up to the third term is enough for obtaining $J(1440)$ that fulfills the requirements. The same power series with Mādhava's coefficients (see Appendix B) produces the same value, $J(1440)=1398 ; 15,27,17,3$, as has been obtained for $n$ greater than 4 with Mādhava's $R$.

Table 1: $J(1440)$ by Mādhava's power series 
Table 2: Data and the values obtained by calculation

\begin{tabular}{|c|c|c|c|c|c|c|}
\hline & $\begin{array}{c}\text { a. } \\
\overline{\text {Arya}}\end{array}$ & $\begin{array}{c}\text { b. } \\
\text { corr. Ārya }\end{array}$ & $\begin{array}{c}\text { c. } \\
\text { Govinda }\end{array}$ & $\begin{array}{c}\text { d. } \\
\text { Mādhava }\end{array}$ & $\begin{array}{c}\text { e. } \\
\text { Nīla-A1 }\end{array}$ & $\begin{array}{c}\text { f. } \\
\text { Nīla-A2 }\end{array}$ \\
\hline$R$ & 3438 & 3438 & $3437 ; 44,19$ & $3437 ; 44,48$ & $3437 ; 28$ & $3437 ; 44,47$ \\
\hline$J_{6}$ & 1315 & 1316 & $1315 ; 33,56$ & $1315 ; 34,07$ & $1315 ; 32$ & $1315 ; 34,07$ \\
\hline$J_{7}$ & 1520 & 1521 & $1520 ; 28,22$ & $1520 ; 28,35$ & $1520 ; 26$ & $1520 ; 28,35$ \\
\hline$K_{6}$ & 210 & 211 & $210 ; 32,26$ & $210 ; 32,29$ & $210 ; 32$ & $210 ; 32,29$ \\
\hline$K_{7}$ & 205 & 205 & $203 ; 54.26$ & $204 ; 54,28$ & $204 ; 54$ & $204 ; 54,28$ \\
\hline$J_{6}^{\prime}\left(=J_{18}\right)$ & 3177 & 3176 & $3176 ; 03,23$ & $3176 ; 03,50$ & $3175 ; 53$ & $3176 ; 03,49$ \\
\hline \multicolumn{7}{|l|}{$J(1440)$} \\
\hline Lower limit $(\S 3)^{* 1}$ & $1398 ; 23, \ldots$ & $1398 ; 23, \ldots$ & $1398 ; 10, \ldots$ & $1398 ; 10, \ldots$ & $1397 ; 57, \ldots$ & $1398 ; 10, \ldots$ \\
\hline Upper limit $(\S 3)^{* 2}$ & $1398 ; 32, \ldots$ & $1398 ; 32, \ldots$ & $1398 ; 20, \ldots$ & $1398 ; 20, \ldots$ & $1398 ; 06, \ldots$ & $1398 ; 20, \ldots$ \\
\hline Linear Int. $(\S 4)$ & $1397 ; 00$ & $1398 ; 00$ & $1397 ; 31,42$ & $1397 ; 31,54$ & $1397 ; 30$ & $1397 ; 31,54$ \\
\hline Nīlakaṇtha’s Int. (§5) & $1397 ; 42$ & $1398 ; 41$ & $1398 ; 15,18$ & $\underline{1398 ; 15,39}$ & $1398 ; 07$ & $1398 ; 15,27$ \\
\hline Mādhava’s Int. (§6) & $1397 ; 43$ & $1398 ; 41$ & $\overline{1398 ; 15,49}$ & $\overline{1398,16,01}$ & $1398 ; 14$ & $1398 ; 16,00$ \\
\hline Brahma’s Int. (§7) & $1397 ; 36$ & $1398 ; 43$ & $1398 ; 12,16$ & $1398 ; 12,28$ & $1398 ; 10$ & $1398 ; 12,28$ \\
\hline Govinda’s Int. (§8) & $1399 ; 54$ & $1401 ; 29$ & $1400 ; 58,33$ & $1400 ; 57,50$ & $1400 ; 46$ & $1400 ; 47,50$ \\
\hline Bhāskara’s App. (§9) & $1400 ; 47$ & $1400 ; 47$ & $1400 ; 41,06$ & $1400 ; 41,17$ & $1400 ; 34$ & $1400 ; 41,16$ \\
\hline Mādhava’s P.S. $(\S 10)^{* 3}$ & $1398 ; 16$ & $1398 ; 16$ & $1398 ; 15,32$ & $1398 ; 15,32$ & $1398 ; 15$ & $1398 ; 15,32$ \\
\hline Mādhava’s P.S. $(\S 10)^{* 4}$ & $1398 ; 16$ & $1398 ; 16$ & $1398 ; 15,26$ & $1398 ; 15,27$ & $1398 ; 15$ & $1398 ; 15,27$ \\
\hline Mādhava’s P.S. $(\S 10)^{* 5}$ & & & & $1398 ; 15,27$ & & \\
\hline
\end{tabular}

${ }^{{ }^{1} 1} R^{2} / 8452 ; 30 .{ }^{{ }^{2}} R^{2} / 8451 ; 30 .{ }^{* 3}$ Calculated up to the 3 rd term. ${ }^{* 4}$ Calculated up to the 4 th term. ${ }^{* 5}$ With Mādhava's coefficients.

\section{VAṬEśvara's VALUE OF $\boldsymbol{J}(\mathbf{1 4 4 0 )}$}

At the beginning of the second chapter of his Siddhānta, Vateśvara gives a $J_{i}$ table [VS 2.1.227a] and a versed sine table [VS 2.1.27-49] up to vikala with $R=3437 ; 44$ and $n=96$. And in the next verse [VS 2.1.50] he states that $R^{2}=$ $11818047 ; 35$ and $J(1440)=1398 ; 13$. Interestingly, these values produce 8452 : $R^{2}=J(1440)=11818047 ; 35 / 1398 ; 13=8452 ; 13$, $44, \ldots$

His value of $R$ is a variation of Āryabhata's value 3438 . That is, from $21600 /(2 R)=62832 /$ 20000 we have $R=\left(216 \cdot 10^{6}\right) / 62832=3437 ; 44$, $19,26,4, \ldots \approx 3437 ; 44$. His value of $R^{2}$ can be obtained either from $3437 ; 44,19,26^{2}=11818047$; $35,9, \ldots$ or from $\left\{\left(216 \cdot 10^{6}\right) / 62832\right\}^{2}=(46656$. $\left.10^{12}\right) / 3947860224=11818047 ; 35 ; 18$; ... As has been pointed out by Shukla [see his note on VS 2.1.61 (part 2, p.170)], $J(1440)=1398 ; 13$ can be obtained from Vateśvara's $J_{i}$ table with $n=96$ by means of the linear interpolation modified for that table [VS 2.1.61]:

$$
J(\theta)=J_{i}+\frac{\left(J_{i+1}-J_{i}\right) r}{15},
$$

where $\theta$ is expressed in degree and $i$ and $r$ are respectively the quotient and the remainder of the division, $96 \theta / 90$ or $16 \theta / 15$. When $\theta=24$, we have $i=25$ and $r=9$. In Vateśvara's $J_{i}$ table, $J_{25}=1367$; 21 and $J_{26}=1418 ; 47$ [Mallayya (2014), p.149]. Hence follows: $J(1440)=1367 ; 21+\{(1418 ; 47$ $-1367 ; 21) \cdot 9\} / 15=1367 ; 21+30 ; 51,36=1398$; $12,36 \approx 1398 ; 13$.

\section{Conclusion}

Table 2 shows the data and the results of calculation of the six cases $(a, b, c, d, e, f)$ treated in $\S 4-\S 10$ above. The sixteen values underlined fulfill the requirements. Among these, the most probable candidate for the value of $J(1440)$ used by Nîlakantha for deriving 8452 is $1398 ; 15,27$ or 1398,15 (see also Appendix C) obtained from his second table of $J_{i}$ by means of his own interpolation ( $5 \mathrm{f}$ ), but 8452 can be produced also 
by $1398 ; 16,1$ or $1398 ; 16$ obtained from Mādhava's $J_{i}$ with $R=3437$; 44, 48 (6d) and $1398 ; 16,0$ or $1398 ; 16$ obtained from Nīlakantha's own $J_{i}$ with $R=3437 ; 44,47$ (6f), both by means of Mādhava's second order interpolation; and by $1398 ; 15,32$ or $1398 ; 16$ and $1398 ; 15,27$ or $1398 ; 15$ obtained either for $R=3437 ; 44 ; 48$ or for $3437 ; 44,47$ by means of Mādhava's power series (10d and 10f); the latter value is also obtained by means of Mādhava's power series with his five coefficients (10d). The same two values, 1398;15 and 1398;16, can also be obtained from Govindasvāmin's $J_{i}$ with $R=3437$; 44; 19 either by Mādhava's interpolation (6c), or by Nīlakantha's interpolation (5c), or by Mādhava's power series (10c). The number 8452 can also be yielded by Vateśvara's $J(1440)=$ $1398 ; 13$, which has been obtained from his $J_{i}$ table with $n=96$ and $R=3437 ; 44$ by means of the linear interpolation.

Brahmagupta's second order interpolation too produces 8452 from Govindasvāmin's $J_{i}$ with $R=3437 ; 44,19$ (7c), from Mādhava's $J_{i}$ with $R$ $=3437 ; 44,48(7 \mathrm{~d})$, and from Nīlakantha's $J_{i}$ with $R=3437 ; 44,47$ (7f), but it is unlikely that the Kerala astronomers who had their own methods of interpolation ventured to use Brahmagupta's even if they knew it.

\section{APPENDices}

\section{A. Reconstruction of Nīlakantha's table of $\boldsymbol{J}_{\boldsymbol{i}}$}

For constructing an $R$-sine table or a table of $J_{i}$, Nīlakantha prescribes, in addition to the traditional diagrammatical method [GS 3.6-9ab], two recursion methods, both of which are based on the principle that the second order sine difference is proportionate to the sine, a principle stated in the Aryabhatya [AB 2.12], that is,

$$
K_{i}-K_{i+1}=\left(K_{1}-K_{2}\right) \frac{J_{i}}{J_{1}}
$$

which in turn is based on the relationship,

$$
\frac{K_{i}-K_{i+1}}{J_{i}}=\left(\frac{a}{R}\right)^{2},
$$

where $a$ is the 'whole chord' (samasta-jya $\overline{\text { ) }}$ subtending one unit arc $(\alpha)$ [Hayashi (1997)]. The only difference between the two methods lies in the accuracy of the coefficients for (i.e., divisors of) $J_{i}$ in the formulas for $K_{i+1}$, that is, 233;30 in method 1 and 233;31,38,13 in method 2.

A1. Method 1 [TS 2.3cd-6ab]

$$
\begin{aligned}
& J_{1}=K_{1}=224 ; 50, K_{i+1}=K_{i}-\frac{J_{i}}{233 ; 30}, \\
& J_{i+1}=K_{1}+K_{2}+\ldots+K_{i+1} .
\end{aligned}
$$

If we calculate $K_{i}$ and $J_{i}$ according to this method, rounding off the third sexagesimal place of the quotient of the division by $233 ; 30$ to the nearest tatpara $\bar{a}$ at each step, we obtain the two columns designated A1 of Table 3 . As the initial value $\left(J_{1}=K_{1}\right)$ has the figures down to the first sexagesimal place (vikalā) only, other $K_{i}$ and $J_{i}$ are also valid up to that place.

A2. Method 2 [TS 2.6cd-10ab]

$$
\begin{aligned}
& 2 R=\frac{21600.113}{355}, J_{23}=J_{1}^{\prime}=\sqrt{J_{24}^{2}-J_{1}^{2}}, \\
& K_{i}-K_{i+1}=\frac{2\left(J_{24}-J_{23}\right) J_{i}}{R} .
\end{aligned}
$$

Nìlakantha gives the last equation in his Golasāra aslo [GS 13cd-14ab] after rewriting it with $J_{24}-J_{23}=K_{24}$. He cites the same verse in his commentary on the second chapter of the Áryabhatīya [NAB2, p.53, lines 12-13] and proves it in the lines that follow. Cf. [Hayashi et al. (1997), pp.108-11]. For a modern proof of the same equation see [Ramasubramanian et al. (2011), pp.62-63].

From the rst equation we have $J_{24}=R=$ $3437 ; 44,47,19, \ldots$ By means of Mādhava's power series (see $\S 10$ above) we have $J_{1}=K_{1}=224 ; 50$; 
Table 3: Nīlakaṇtha's $J_{i}$ tables reconstructed

\begin{tabular}{|c|c|c|c|c|}
\hline \multirow[t]{2}{*}{$i$} & \multicolumn{2}{|c|}{ A1(acc. to TS 2.3cd-6ab) } & \multicolumn{2}{|c|}{ A2 (acc. to TS 2.6cd-10ab) } \\
\hline & $\boldsymbol{K}_{i}$ & ${ }^{* 1} J_{i}$ & $\boldsymbol{K}_{i}$ & $J_{i}$ \\
\hline 1 & $224 ; 50$ & $224 ; 50$ & $224 ; 50,21,50$ & $224 ; 50,21,50$ \\
\hline 2 & $223 ; 52,14$ & $448 ; 42,14$ & $223 ; 52,35,46$ & $448 ; 42,57,36$ \\
\hline 3 & $221 ; 56,56$ & $670 ; 39,10$ & $221 ; 57,18,28$ & $670 ; 40,16,04$ \\
\hline 4 & $219 ; 04,36$ & $889 ; 43,46$ & $219 ; 04,59,34$ & $889 ; 45,15,38$ \\
\hline 5 & $215 ; 15,59$ & $1104 ; 59,45$ & $215 ; 16,23,20$ & $1105 ; 01,38,58$ \\
\hline 6 & $210 ; 32,03$ & $1315 ; 31,48$ & $210 ; 32,28,30$ & $1315 ; 34,07,28$ \\
\hline 7 & $204 ; 54,01$ & $1520 ; 25,49$ & $204 ; 54,28,01$ & $1520 ; 28,35,29$ \\
\hline 8 & $198 ; 23,20$ & $1718 ; 49,09$ & $198 ; 23,48,43$ & $1718 ; 52,24,12$ \\
\hline 9 & $191 ; 01,40$ & $1909 ; 50,49$ & $191 ; 02,10,59$ & $1909 ; 54,35,11$ \\
\hline 10 & $182 ; 50,55$ & $2092 ; 41,44$ & $182 ; 51,28,17$ & $2092 ; 46,03,28$ \\
\hline 11 & $173 ; 53,11$ & $2266 ; 34,55$ & $173 ; 53,46,41$ & $2266 ; 39,50,09$ \\
\hline 12 & $164 ; 10,46$ & $2430 ; 45,41$ & $164 ; 11,24,20$ & $2430 ; 51,14,29$ \\
\hline 13 & $153 ; 46,10$ & $2584 ; 31,51$ & $153 ; 46,50.53$ & $2584 ; 38,05,22$ \\
\hline 14 & $142 ; 42,03$ & $2727 ; 13,54$ & $142 ; 42,46,47$ & $2727 ; 20,52,09$ \\
\hline 15 & $131 ; 01,16$ & $2858 ; 15,10$ & $131 ; 02,02,39$ & $2858 ; 22,54,48$ \\
\hline 16 & $118 ; 46,49$ & $2977 ; 01,59$ & $118 ; 47,38,32$ & $2977 ; 10,33,20$ \\
\hline 17 & $106 ; 01,50$ & $3083 ; 03,49$ & $106 ; 02,43,07$ & $3083 ; 13,16,27$ \\
\hline 18 & $92 ; 49,37$ & $3175 ; 53,26$ & $92 ; 50,32,56$ & $3176 ; 03,49,23$ \\
\hline 19 & $79 ; 13,32$ & $3255 ; 06,58$ & $79 ; 14,31,30$ & $3255 ; 18,20,53$ \\
\hline 20 & $65 ; 17,06$ & $3320 ; 24,04$ & $65 ; 18,08,30$ & $3320 ; 36,29,23$ \\
\hline 21 & $51 ; 03,54$ & $3371 ; 27,58$ & $51 ; 04,58,49$ & $3371 ; 41,28,12$ \\
\hline 22 & $36 ; 37,34$ & $3408 ; 05,32$ & $36 ; 38,41,39$ & $3408 ; 20,09,51$ \\
\hline 23 & $22 ; 01,50$ & $3430 ; 07,22$ & $22 ; 02,59,34$ & ${ }^{*} 3430 ; 23,09,25$ \\
\hline 24 & $7 ; 20,26$ & $3437 ; 27,48$ & $7 ; 21,37,34$ & ${ }^{*} 3437 ; 44,46,59$ \\
\hline
\end{tabular}

${ }^{* 1}$ [Ramasubramanian et al. (2011), p.64] lists $J_{i}$ of A1 up to vikalä (first sexagesimal place). Those values can be obtained

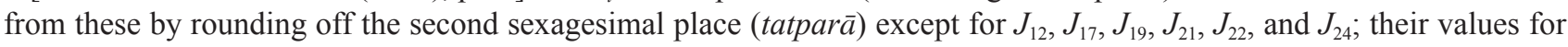
these $J_{i}$ differ by one vikala from the values in this list after the second sexagesimal place is rounded off.

${ }^{* 2}$ These values for $J_{23}$ and $J_{24}$ are less than those used in the calculation of the divisor, 233;31,38,13, of $J_{i}$ (see Appendix A2) by $0 ; 0,0,10$ and $0 ; 0,0,20$, respectively.

21; 50 ; from the second equation $J_{23} \approx 3430 ; 23$; 9; 35; and therefore

$$
\frac{R}{2\left(J_{24}-J_{23}\right)}=\frac{3437 ; 44,47,19}{14 ; 43,15,28}=233 ; 31,38,13, \ldots
$$

By substituting the reciprocal of this value in the third equation, we have

$$
K_{i+1}=K_{i}-\frac{J_{i}}{233 ; 31,38,13} .
$$

If we calculate $K_{i}$ and $J_{i}$ according to this method, rounding off the fourth sexagesimal place of the quotient of the division by $233 ; 31,38,13$ at each step, we obtain the two columns designated A2 of Table 3 . These $J_{i}$, except $J_{15}$ and $J_{23}$, are the same as those obtained by means of the diagrammatical method [GS3.6-9ab] with $C / d=$ $355 / 113$ [GS 3.12ab] after the third sexagesimal places are rounded off. See [Mallayya (2014), p.153, Table 9], which has $2858 ; 22,54.16(\approx 2858$; $22,54)$ for $J_{15}$ and $3430 ; 23,09.60(\approx 3430 ; 23,10)$ for $J_{23}$. 
Table 4: Possible derivations of Mādhava's $J i$

\begin{tabular}{|c|c|c|c|c|c|}
\hline \multirow[t]{2}{*}{$i$} & \multirow{2}{*}{$\begin{array}{c}\text { Mādhava's } \\
\text { (in } 6 \text { verses) } \\
J_{i}\end{array}$} & \multirow{2}{*}{$\begin{array}{c}\text { B1 } \\
\text { (by power series) } \\
J_{i}\end{array}$} & \multirow{2}{*}{$\begin{array}{c}\text { B2 } \\
\text { (with coefficients) } \\
J_{i}\end{array}$} & \multicolumn{2}{|c|}{$\begin{array}{c}\text { B3 } \\
\text { (by sine difference) }\end{array}$} \\
\hline & & & & $K_{i}$ & $J_{i}$ \\
\hline 1 & $0224 ; 50,22$ & $224 ; 50,21,49,36$ & $224 ; 50,21,49,36$ & $224 ; 50,21,50$ & $224 ; 50,21,50$ \\
\hline 2 & $0448 ; 42,58$ & $448 ; 42,57,35,05$ & $448 ; 42,57,35,05$ & $223 ; 52,35,46$ & $448 ; 42,57,36$ \\
\hline 3 & $0670 ; 40,16$ & $670 ; 40,16,02,49$ & $670 ; 40,16,02,49$ & $221 ; 57,18,28$ & $670 ; 40,16,04$ \\
\hline 4 & $0889 ; 45,15$ & $* 889 ; 45,15,36,34$ & $* 889 ; 45,15,36,31$ & $219 ; 04,59,34$ & $* 889 ; 45,15,38$ \\
\hline 5 & $1105 ; 01,39$ & $1105 ; 01,38,56,06$ & $1105 ; 01,38,56,19$ & $215 ; 16,23,20$ & $1105 ; 01,38,58$ \\
\hline 6 & $1315 ; 34,07$ & $1315 ; 34,07,26,06$ & $1315 ; 34,07,26,06$ & $210 ; 32,28,30$ & $1315 ; 34,07,28$ \\
\hline 7 & $1520 ; 28,35$ & $1520 ; 28,35,26,48$ & $1520 ; 28,35,27,01$ & $204 ; 54,28,01$ & $1520 ; 28,35,29$ \\
\hline 8 & $1718 ; 52,24$ & $1718 ; 52,24,10,17$ & $1718 ; 52,24,10,17$ & $198 ; 23,48,43$ & $1718 ; 52,24,12$ \\
\hline 9 & $1909 ; 54,35$ & $1909 ; 54,35,10,06$ & $1909 ; 54,35,09,53$ & $191 ; 02,10,59$ & $1909 ; 54,35,11$ \\
\hline 10 & $2092 ; 46,03$ & $2092 ; 46,03,27,25$ & $2092 ; 46,03,27,38$ & $182 ; 51,28,17$ & $2092 ; 46,03,28$ \\
\hline 11 & $2266 ; 39,50$ & $2266 ; 39,50,09,44$ & $2266 ; 39,50,09,57$ & $173 ; 53,46,41$ & $2266 ; 39,50,09$ \\
\hline 12 & $2430 ; 51,15$ & $2430 ; 51,14,31,59$ & $2430 ; 51,14,32,12$ & $164 ; 11,24,21$ & $2430 ; 51,14,30$ \\
\hline 13 & $2584 ; 38,06$ & $* 2584 ; 38,05,27,36$ & $* 2584 ; 38,05,27,48$ & $153 ; 46,50,54$ & *2584; $38,05,24$ \\
\hline 14 & $2727 ; 20,52$ & $2727 ; 20,52,17,45$ & $2727 ; 20,52,17,32$ & $142 ; 42,46,48$ & $2727 ; 20,52,12$ \\
\hline 15 & $2858 ; 22,55$ & $2858 ; 22,54,59,54$ & $2858 ; 22,54,59,54$ & $131 ; 02,02,40$ & $2858 ; 22,54,52$ \\
\hline 16 & $2977 ; 10,34$ & $2977 ; 10,33,36,00$ & $2977 ; 10,33,36,00$ & $118 ; 47,38,33$ & $* 2977 ; 10,33,25$ \\
\hline 17 & $3083 ; 13,17$ & $3083 ; 13,16,47,03$ & $3083 ; 13,16,46,50$ & $106 ; 02,43,08$ & $3083 ; 13,16,33$ \\
\hline 18 & $3176 ; 03,50$ & $3176 ; 03,49,47,03$ & $3176 ; 03,49,47,29$ & $92 ; 50,32,57$ & $3176 ; 03,49,30$ \\
\hline 19 & $3255 ; 18,22$ & $* 3255 ; 18,21,22,36$ & $* 3255 ; 18,21,22,49$ & $79 ; 14,31,31$ & *3255; 18,21,01 \\
\hline 20 & $3320 ; 36,30$ & $3320 ; 36,29,58,12$ & $3320 ; 36,29,58,50$ & $65 ; 18,08,31$ & $3320 ; 36,29,32$ \\
\hline 21 & $3371 ; 41,29$ & $3371 ; 41,28,53,06$ & $3371 ; 41,28,53,58$ & $51 ; 04,58,50$ & $* 3371 ; 41,28,22$ \\
\hline 22 & $3408 ; 20,11$ & $3408 ; 20,10,38,12$ & $3408 ; 20,10,39,30$ & $36 ; 38,41,40$ & $* 3408 ; 20,10,02$ \\
\hline 23 & $3430 ; 23,11$ & $* 3430 ; 23,10,18,46$ & $* 3430 ; 23,10,20,29$ & $22 ; 02,59,35$ & *3430;23,09,37 \\
\hline 24 & $3437 ; 44,48$ & $3437 ; 44,48,00,43$ & $3437 ; 44,48,00,04$ & $7 ; 21,37,35$ & *3437; 44,47,12 \\
\hline
\end{tabular}

\section{B. Derivation of Mādhava's table of $J_{i}$}

Mādhava's versified table of $J_{i}$ (see the second column of Table 4) is cited by Nīlakantha in his commentary on the Aryabhatiya [NAB2, p.55, lines 10-22] and by Śankara Vāriyar in his prose commentary on the Tantrasamgraha [TS 2.6cd-10ab; cf. Ramasubramanian et al. (2011), p.63]. The values given in the six verses agree fairly well, though not perfectly, with those obtained by means of Mādhava's power series for $J(x)$.

Śankara in his metrical commentary Yuktidīpika on the Tantrasamgraha [YD 2.440$41 \approx 2.451-52]$ and in his prose commentary on the Lìlavatī [KK on L 199, p.390] anonymously quotes Mādhava's rule for $J(x)$ for any arc $x$ expressed in kala , which may be expressed in modern notation as follows.

Let $f_{i}(i \geq 2)$ be dened as

$$
f_{i}=\frac{x^{2}}{\left\{(2 i-2)^{2}+(2 i-2)\right\} R^{2}} .
$$

Put $x$ and $f_{i}$ vertically one below the othercolumn (1) in the next diagram; starting from the top, multiply the upper into the lower in succession - (2); and, starting from the bottom, subtract the lower from the upper in succession; the result is $J(x)-(3)$. 


\begin{tabular}{ll}
$(1)$ & $(2)$ \\
\hline$x$ & $x$ \\
$f_{2}$ & $x f_{2}$ \\
$f_{3}$ & $x f_{2} f_{3}$ \\
$\cdot$ & $\cdot$ \\
$\cdot$ & $\cdot$ \\
$\cdot$ & $\cdot$ \\
$f_{n-1}$ & $x f_{2} f_{3} \cdots f_{n-1}$ \\
$f_{n}$ & $x f_{2} f_{3} \cdots f_{n-1} f_{n}$ \\
\hline
\end{tabular}

(3)

$$
\begin{aligned}
& J(x)=x-\left(x f_{2}-\left(x f_{2} f_{3}-\cdots\right.\right. \\
& \left.\left.-\left(x f_{2} f_{3} \cdots f_{n-1}-x f_{2} f_{3} \cdots f_{n}\right)\right)\right) .
\end{aligned}
$$

This (3) may be rewritten as

$$
\begin{aligned}
& J(x)=x-x \cdot \frac{x^{2}}{\left(2^{2}+2\right) R^{2}}+x \cdot \frac{x^{2}}{\left(2^{2}+2\right) R^{2}} \cdot \frac{x^{2}}{\left(4^{2}+4\right) R^{2}}-\ldots \\
& +(-1)^{n-1} x \cdot \frac{x^{2 n-2}}{\left(2^{2}+2\right)\left(4^{2}+4\right) \ldots\left\{(2 n-2)^{2}+(2 n-2)\right\} R^{2 n-2}}
\end{aligned}
$$

In passing, this is equivalent to:

$$
\sin \theta=\theta-\frac{\theta^{3}}{3 !}+\frac{\theta^{5}}{5 !}-\ldots+(-1)^{n-1} \frac{\theta^{2 n-1}}{(2 n-1) !} .
$$

Now, if we put $y=x / 5400$, the above formula with the first six terms of the right-hand side can be rewritten as

$$
J(x)=x-a_{1} y^{3}+a_{2} y^{5}-a_{3} y^{7}+a_{4} y^{9}-a_{5} y^{11},
$$

where, for Mādhava's $R=3437 ; 44,48$,

$$
\begin{aligned}
& a_{1}=\frac{5400^{3}}{3 ! R^{2}}=2220 ; 39,40, a_{2}=\frac{5400^{5}}{5 ! R^{4}}=273 ; 57,47, \\
& a_{3}=\frac{5400^{7}}{7 ! R^{6}}=16 ; 5,41, \quad a_{4}=\frac{5400^{9}}{9 ! R^{8}}=0 ; 33,6, \\
& a_{5}=\frac{5400^{11}}{11 ! R^{10}}=0 ; 0,44 .
\end{aligned}
$$

A quarter verse that reads these five coefficients in the Katapayādi notation is quoted by Nīlakantha [NAB2.17cd, p.113, line 7] and by Śankara [YD 2.437a, p.117]. Cf. [Gupta (1976); Gold and Pingree (1991); Pingree (2003), pp.4951].

The third column of Table 4 (B1) shows the results of the calculations by the power series with Mādhava's $R=3437 ; 44,48$ and $n=7$. The four asterisked values differ from Mādhava's by one tatpar $\bar{a}$ when their third sexagesimal places are rounded off. The fourth column (B2) shows the values obtained by Mādhava series with Mādhava's coefficients up to the sixth term. Here also, the same four $J_{i}$, asterisked, differ from Mādhava's by one tatparā.

For comparison, I also put in the same table the values of $K_{i}$ and $J_{i}$ obtained by means of the recursive formula for the sine differences as in Appendix A2 above. Here I use, instead of 355/ 113 used by Nilakantha in the first of the three equations, Mādhava's ratio of the circumference to the diameter, $C / d=2827433388233 /\left(9 \cdot 10^{11}\right)$, cited by Nīlakantha [NAB2, p.42] and by Śankara [KK, p.377]. From this we obtain $J_{24}=R=3437$; $44,48,22, \ldots$; by means of Mādhava's power series $J_{1}=K_{1}=224 ; 50,21,50, \ldots$ as above; from the second equation $J_{23} \approx 3430 ; 23,10,38$; and therefore,

$$
\frac{R}{2\left(J_{24}-J_{23}\right)}=\frac{3437 ; 44,48,22}{14 ; 43,15,28}=233 ; 31,38,17 \ldots
$$

Finally from the third equation, we have

$$
K_{i+1}=K_{i}-\frac{J_{i}}{233 ; 31,38,17} .
$$

As in Appendix A2, if we calculate $K_{i}$ and $J_{i}$ according to this method, rounding off the fourth sexagesimal place of the quotient of the division by $233 ; 31,38,17$ at each step, we obtain the two columns designated B3 of Table 4 . The eight asterisked values differ from Mādhava's by one tatpar $\bar{a}$ when their third sexagesimal places are rounded off. 
Of course, Mādhava could have used the diagrammatical procedure alluded to in the Áryabhatīya [AB 2.11] etc. (cf. [Hayashi (1997), p.403]) and it would have brought him more accurate values. But every step of that procedure involves square-root computation as the procedure consists of the two formulas:

$$
J_{24-i}=\sqrt{R^{2}-J_{i}^{2}} \text { and } J_{\frac{i}{2}}=\frac{\sqrt{J_{i}^{2}+\left(R-J_{24-i}\right)^{2}}}{2} .
$$

It is therefore very cumbersome especially with numbers expressed partly in decimal and partly in sexagesimal notation. This may have been the reason why he, as well as others, avoided this procedure.

\section{Confirmation}

The anonymous referee of this paper rightly pointed out that I had missed the following three cases: (1) Vateśvara's value of $J(1440),(2)$ 'similar approximations' that occur in Nīlakantha's auto-commentary on the CC (8452 on p.8 and 1398 on p.16), and (3) Govindasvāmin's interpolation. ' 8452 ' of case (2) does not provide new information; case (3) has been included in later versions of the draft; and (1) was newly incorporated as $\S 11$. But more important is ' 1398 on p.16' of case (2), which leads us to the confirmation of a candidate for $J(1440)$.

It occurs in an Anuṣtubh verse of Nīlakaṇtha, which he cites in his own commentary on CC 19-21. The verse in the published edition reads:

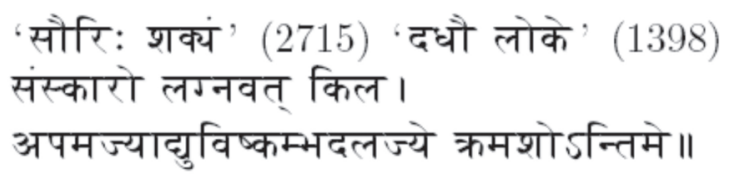

The editor admits numerical values (expressed in the Katapayādi notation) only in the first $p \bar{a} d a$. Here he seems to be confused: he first divides it into three parts, sauriḥ(27), śakyam (15), and dadhau loke (1398), and then combines the first two numbers into one (2715), so that the first pāda signifies the two numbers, 2715 and 1398. Certainly two numbers are expected in this verse because it is introduced by the words, 'The maximum declination is stated as bhapakramah ('declination 24') [in AB 1.8a]. ... Its complementary arc is sixty-six degrees. Their $<$ half $>$ chords have been obtained and read $<$ in verse by us as follows $>$.' Now, 1398 may be an approximation to $J\left(24^{\circ}\right)$, but 2715 cannot be an approximation to $J\left(66^{\circ}\right)$. Nor can I find any meaning (or role) of it. So, I propose to read one number each in the first and the second pādas, both in eight digits, as follows (I emended sakyam, which does not make sense in this context, to salyam, which does not change the numerical meaning).

$$
\begin{aligned}
& \text { सौरि: शल्यं दधौ लोके (अ२प ?५०३३?) } \\
& \text { संस्कारो लग्नवत्किल (१९२३०८९३)। } \\
& \text { अपमज्याद्युविष्कम्भदलज्ये कमशो न्तिमे॥ }
\end{aligned}
$$

Saturn put distress upon the world (72518931); purification at an auspicious moment $<$ is necessary $>$ indeed (71230413). $<$ These are $>$ respectively the chord of the declination and the chord of the semi-diameter of the diurnal <circle of the sun $>$, both being final.

In other words, 1398;15,27 and $3140 ; 32,17$ are respectively the half chords ( $J$ 's or Rsines) of the sun's maximum declination $\left(24^{\circ}\right.$ or 1440 kalās $)$ and its complementary arc $\left(66^{\circ}\right.$ or 3960 kalās):

$$
\begin{aligned}
& J(1440)=1398 ; 15,27, \\
& J(3960)=3140 ; 32,17 .
\end{aligned}
$$

Remarkably, by this reading, the first $p \bar{a} d a$ of the cited verse turns out to have given exactly the same value of $J(1440)$ that we have already obtained by means of Mādhava's power series both from Mādhava's $R=3437 ; 44,48$ and from Nīlakaṇtha's $R=3437 ; 44,47$ (see Table 1), and also by means of Nīlakaṇtha's interpolation (see 
$5 \mathrm{f}$ and Table 2) from his second table of $J_{i}$ with $R$ =3437; 44,47 (Appendix A2).

The above interpretation of the cited verse is confirmed with regard to the second $p \bar{a} d a$ also; nearly the same values of $J(3960)$ are obtained in the same manner. By Mādhava's power series (see $\S 10)$ we have $J(3960)=3140 ; 32,16,26,36 \approx 3140$; 32, 16 from Mādhava's $R$ and 3140; 32, 15, 59,49 $\approx 3140 ; 32,16$ from Nīlakantha's $R$, when $n \geq 7$ (when $n=5$, Nilakantha's $R$ happens to produce $3140 ; 32,17,27,18 \approx 3140 ; 32,17)$. The same approximation is obtained by Nīlakantha's interpolation (see $\S 5$ ), too:

$$
\begin{aligned}
J(3960) & =J^{\prime}(1440)=\frac{J_{6}^{\prime} \cdot J^{\prime}(90)-J_{6} \cdot J(90)}{R} \\
& =3140 ; 32,15,38, \ldots \approx 3140 ; 32,16 . \\
& \text { Of course, the Pythagorean theorem }
\end{aligned}
$$
could also be used to produce $J(3960)$ as the arc 3960 is complementary to 1440 : $J(3960)=\sqrt{R^{2}-J(1440)^{2}}$. Thus, we have $3140 ; 32,15,45, \ldots \approx 3140 ; 32,16$ from Mādhava's $R$ and $3140 ; 32,15,14, \ldots \approx 3140 ; 32,15$ from Nīlakantha's.

\section{ACKNOWLedgment}

I am grateful to the anonymous referee whose valuable comments helped me improve this paper (see Appendix C).

\section{BIBLIOGRAPHY}

\section{Primary sources}

Āryabhatīya of Āryabhata (Abbrev: AB) ed. with the commentary of Bhāskara I and Someśvara, Indian National Science Academy, New Delhi, 1976.

Āryabhațīyabhāṣya of Nīlakaṇtha, Gaṇitapāda (Abbrev: NAB2) ed. by K. S. Śāstrī, Trivandrum Sanskrit Series 101, University of Trivandrum, Trivandrum, 1930.
Āryabhațīyabhāsya of Nīlakanțha, Golapāda (Abbrev: NAB4) ed. by S. K. Pillai, Trivandrum Sanskrit Series 185, University of Trivandrum, Trivandrum, 1957.

Brāhmasphutasiddhānta of Brahmagupta (Abbrev: BSS) ed. by S. Dvivedin, Medical Hall Press, Benares, 1902.

Candracchāyāganita of Nīlakantha (Abbrev: CC) ed. with an English translation by K.V. Sarma, Panjab University Indological Series 6, Panjab University, Hoshiarpur, 1976.

Golādhyaya of Bhāskara II (Abbrev: GA) ed. by M. Dh. Chaturvedi in: Siddhāntaśiromani of Bhāskarācārya, Library Rare Text Publication Series 5, Sampurnanand Sanskrit University, Varanasi, 1981.

Golāsara of Nīlakantha (Abbrev: GS) ed. by K. V. Sarma, Vishveshvaranand Indological Series 47, Vishveshvaranand Institute, Hoshiarpur, 1970.

Grahaganitādhāya of Bhāskara II (Abbrev: GG) ed. by M. Dh. Chaturvedi in: Siddhāntaśiromani of Bhāskarācārya, Library Rare Text Publication Series 5, Sampurnanand Sanskrit University, Varanasi, 1981.

Khandakhādyaka of Brahmagupta (Abbrev: KhKh) ed. with Utpala's commentary and an English translation by B. Chatterjee, 2 vols., World Press, Calcutta, 1970.

Kriyākramakarī of Śañkara Vāriyar and Nārāyaṇa (Abbrev: KK). See Līlāvatī of Bhāskara II below.

Lìlāvatī of Bhāskara II (Abbrev: L) ed. with the Kriyākramakarī of Śankara and Nārāyaṇa by K. V. Sarma, Vishveshvaranand Indological Series 66, Vishveshvaranand Institute, Hoshiarpur, 1975.

Mahābhāskarīya of Bhāskara I (Abbrev: MB) ed. with the commentary Bhāṣy of Govindasvāmin and the super commentary Siddhāntadīpikā of Parameśva by T. S. Kuppanna Sastri, Madras Government Oriental Series 130, Government Oriental Manuscripts Library, Madras, 1957.

Mahābhāskarīyabhāşya of Govindasvāmin (Abbrev: GMB). See Mahābhāskarīya of Bhāskara I above.

Tantrasamgraha of Nilakantha (Abbrev: TS) ed. with the Yuktidīpika and Laghuvivrti of Śañkara Vāriyar by K. V. Sarma, Punjab University, Hoshiarpur, 1977.

Vateávarasiddhānta of Vateśvara (Abbrev: VS) ed. with an English translation and notes by K. S. Shukla, 2 parts, Indian National Science Academy, New Delhi, 198586.

Yuktidīpikā of Śankkara Vāriyar (Abbrev: YD). See Tantrasamgraha of Nīlakaṇtha above. 


\section{Secondary sources}

Bag, A. K. Mādhava's Sine and Cosine Series, Indian Journal of History of Science 11(1976): 54-57.

Gold, D. and D. Pingree. A Hitherto Unknown Sanskrit Work concerning Mādhava's Derivation of the Power Series for Sine and Cosine, Historia Scientiarum 42(1991): 49-65.

Gupta, R.C. Second Order Interpolation in Indian Mathematics up to the Fifteenth Century, Indian Journal of History of Science 4(1969): 86-98.

Gupta, R.C. Fractional Parts of Āryabhata's Sines and Certain Rules Found in Govindasvāmin's Bhāṣya on the Mahābhāskarīya, Indian Journal of History of Science 6(1971): 51-59.

Gupta, R.C. Mādhava's Power Series Computation of the Sine, Ganita 27(1976): 19-24.
Hayashi, T. Āryabhața's Rule and Table for SineDifferences, Historia Mathematica 24(1997): 396- 406.

Hayashi, T., T. Kusuba, and M. Yano. Studies in Indian Mathematics: Series, Pi and Trigonometry, in Japanese, Koseisha Koseikaku, Tokyo, 1997.

Knudsen, T. Versified Sine Tables in Jñānarāja's Siddhāntasundara, Indian Journal of History of Science 49(2014): 127-41.

Mallayya, V. M. Trigonometric Tables in India, Indian Journal of History of Science 49(2014): 142- 56.

Pingree, D. The Logic of Non-Western Science: Mathematical Discoveries in Medieval India, Doedalus (Journal of the American Academy of Arts \& Sciences) Fall/2003 (2003): 45-53.

Ramasubramanian, K. and M. S. Sriram. Tantrasangraha of Nīlakanththa Somayājīi, Springer, London etc., 2011. 